\title{
Interleukin-7 Receptor Alpha in Innate Lymphoid Cells: More Than a Marker
}

\author{
Abdalla Sheikh ${ }^{1,2}$ and Ninan Abraham ${ }^{1,2,3 *}$ \\ ${ }^{1}$ Department of Microbiology and Immunology, University of British Columbia, Vancouver, BC, Canada, ${ }^{2}$ Life Sciences \\ Institute, University of British Columbia, Vancouver, BC, Canada, ${ }^{3}$ Department of Zoology, University of British Columbia, \\ Vancouver, BC, Canada
}

Innate lymphoid cells (ILCs) are a group of immune cells that are important for defense against pathogens, tissue repair, and lymphoid organogenesis. They share similar characteristics with various subsets of helper T cells but lack specific antigen receptors. Interleukin-7 (IL-7) and thymic stromal lymphopoietin (TSLP) are cytokines that engage the IL-7R $\alpha$ and have major roles in dictating the fate of ILCs. Recent advances in the field have revealed transcriptional programs associated with ILC development and function. In this article, we will review recent studies of the role of IL-7 and TSLP in ILC development and function during infection and inflammation.

OPEN ACCESS

Edited by:

Arthur Mortha

University of Toronto, Canada

Reviewed by:

Cyril Seillet,

Walter and Eliza Hall Institute of Medical Research, Australia

Ai Ing Lim,

National Institute of Allergy and Infectious Diseases (NIAID),

United States

*Correspondence:

Ninan Abraham ninan@mail.ubc.ca

Specialty section:

This article was submitted to NK and Innate Lymphoid Cell Biology,

a section of the journal

Frontiers in Immunology

Received: 25 September 2019 Accepted: 26 November 2019 Published: 11 December 2019

Citation:

Sheikh A and Abraham N (2019) Interleukin-7 Receptor Alpha in Innate Lymphoid Cells: More Than a Marker.

Front. Immunol. 10:2897.

doi: 10.3389/fimmu.2019.02897
Keywords: IL-7, TSLP, innate lymphoid cells, mucosal immunity, lymphopoiesis, inflammation

\section{INTRODUCTION}

Innate lymphoid cells (ILCs) are a recently discovered subset of immune cells critical for the development of innate immunity against external pathogens, facilitating tissue repair, and mediating inflammation at multiple mucosal sites (1). It has become clear that these cells are major contributors despite being rare in proportion among immune cells. Although they lack antigen receptors, ILCs share multiple developmental circuitries with and are ancestral to the more abundant adaptive lymphoid cells. Both populations of lymphoid cells are known to develop from the same stem cell precursors in the bone marrow called common lymphoid precursors (CLPs) (25). In addition to sharing common progenitors with adaptive cells in the bone marrow, ILCs also require similar growth factors and cytokines to develop and function. The interleukin-7 receptor $\alpha$ (IL-7R $\alpha$ or CD127) dependent cytokines, IL-7 and thymic stromal lymphopoietin (TSLP) are examples of such cytokines and they play an important role in determining the fate and function of ILCs $(1,6,7)$. IL-7 is canonically important for the early development of B and T cells from bone marrow precursors and the thymic development of $\mathrm{T}$ cells $(8,9)$. Mature $\mathrm{T}$ cells also require IL-7 for survival, proliferation and multiple effector functions during infections and tumor infiltration (10-13). TSLP is mainly and constitutively produced by epithelial cells of the skin, gut and lungs, and shapes the response of dendritic cells and $\mathrm{T}$ cells against invading pathogens in a typical type 2 "weep and sweep" response that when misdirected, may also contribute to asthma and allergic inflammation (14-17).

Due to the heterogeneity in ILC populations and their multiple precursors, and our incomplete understanding of the biological factors (transcription factors, cytokines, disease states, etc.) that dictate ILC lineage commitment and function, we lack the knowledge to use ILC biology to develop new treatments or understand the precise role of ILCs in response to current therapeutics. For example, cytokines that govern adaptive lymphoid cells such as rhIL-7 are in multiple clinical trials 
for treatment of HIV, solid tumors, T cell reconstitution, and enhancing CAR-T cell therapy for B-cell lymphomas, yet the effects this may have on ILCs and other disease outcomes is understudied (18). In this review we will discuss relevant findings on the roles of IL-7 and TSLP in ILC development and function at various tissue sites as well as the mechanisms involved downstream of their signals. Where appropriate, we will also identify the significant gaps in the field and possible future directions.

\section{IL-7 AND TSLP}

IL-7R $\alpha$ is found on multiple subsets of lymphoid cells during their developmental and mature states. Both IL-7 and TSLP use IL-7R $\alpha$ to initiate the formation of a heterodimeric receptor. IL-7 is a common gamma chain $\left(\gamma_{c}\right)$ cytokine and requires the heterodimerization of IL-7R $\alpha$ with the $\gamma c$ receptor (CD132) for signaling (19), whereas TSLP signaling requires heterodimerization with the TSLP receptor (TSLPR) $(20,21)$ (Figure 1).

IL-7 is produced mainly by stromal cells in the bone marrow and thymus under steady state where it plays an indispensable role in the development of both pre- and pro-B cells in the bone marrow (22). The dynamic expression of IL-7Ra was shown to be critical for IL-7 responsiveness for specific stages of maturation in the thymus in shaping $\mathrm{T}$ cell development and survival (23-25). In addition to being an essential factor for $\mathrm{B}$ and $\mathrm{T}$ cell development, IL-7 can also influence effector $\mathrm{T}$ cells. For instance, exogenous IL-7 treatment enhances cytotoxic CD8 $\mathrm{T}$ cell anti-tumor activity and reverses $\mathrm{T}$ cell exhaustion caused by chronic LCMV infection, and thus, preventing liver pathology $(10,11)$.

While IL-7 is known to be produced mainly in the stromal and epithelial cells of the bone marrow and thymus respectively, the cells in the various other tissues that are capable of producing this cytokine are elusive (26). It is clear that the main producers are radio resistant cells of non-hematopoietic origin (27). IL7 can be detected at low levels in the small intestine, lungs, liver, and skin where it can modulate $\mathrm{T}$ cell responses (2832). In addition, through use of IL-7-eGFP mice, it became apparent that while stromal and epithelial cells contribute to IL7 production, lymphatic endothelial cells are the key producers of IL-7 throughout the body including mucosal tissues such as the lung $(33,34)$. However, whether these cells are the primary source of IL-7 during inflammation, and if they play a role in ILC responses, remains a question.

What regulates the expression or availability of IL-7 in mucosal barrier tissues is not entirely clear. In the liver, LPS induced TLR stimulation leads to TRIF dependent expression of IL-7 in hepatic cells (28). Whether this mechanism is conserved in other tissues is not known. Interestingly however, while both ILCs and $\mathrm{T}$ cells express IL-7R $\alpha$, the expression of this receptor is significantly higher on ILCs due to an increased resistance to IL-7 mediated internalization (27). As such, ILCs are key regulators of the availability of IL-7 in lymphoid tissues acting as a cytokine sink and limiting IL-7 availability to other cells such as $\mathrm{T}$ cells which depend on IL-7 for homeostatic proliferation (27). Considering T cells heavily outnumber ILCs, further investigation is necessary to determine the extent to which ILCs limit the availability of IL-7 in peripheral tissues and how that affects other immune cells during homeostasis and inflammation.

TSLP was originally identified in a conditioned murine thymic stromal cell line supernatant and reported to play a role in the in vitro development of B cells (35-37). However, loss of function in vivo studies have demonstrated minimal or secondary role for TSLP in lymphoid development (22, 38, 39). IL-7 and TSLP are often compared with each other owing to their

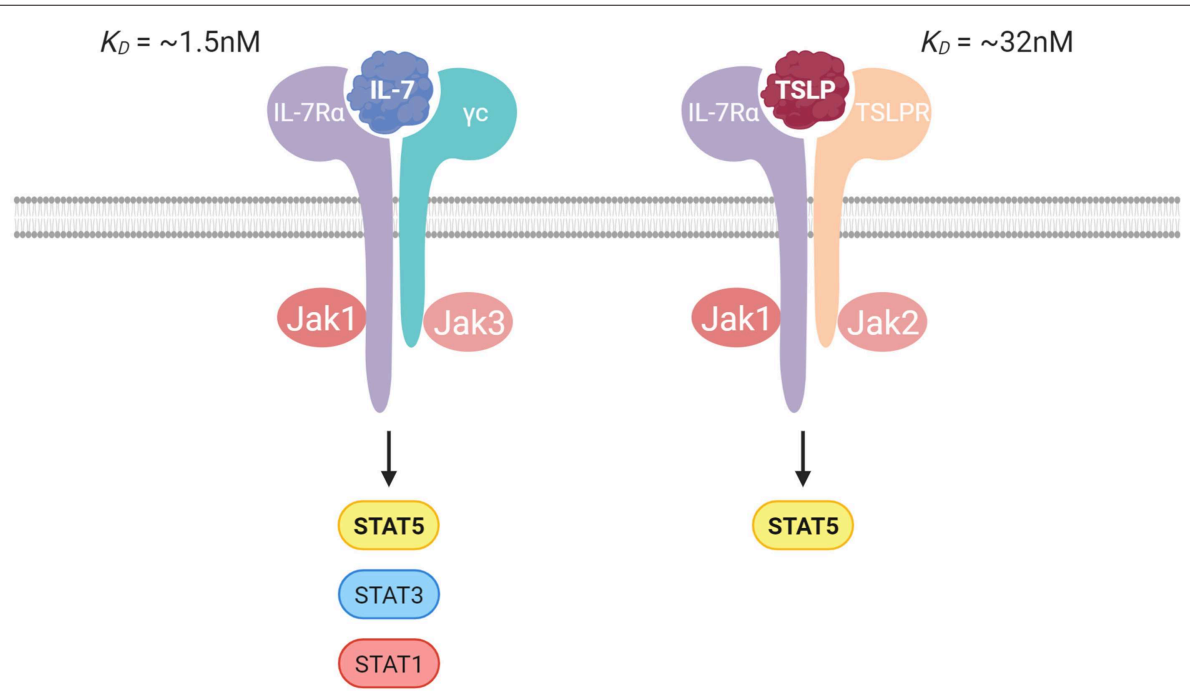

FIGURE 1 | Illustration of the IL-7 and TSLP receptor complexes with the binding affinities. IL-7 signals through IL-7R $\alpha$ paired with the $\gamma \mathrm{C}$ receptor, and TSLP signals through IL-7R $\alpha$ paired with the TSLP receptor. Jak/STAT signaling is crucial in transduction of signal for both cytokines. 
shared dependency on IL-7R $\alpha$ and ability to activate STAT5, albeit through different JAK proteins (40). However, despite its discovery from thymic cells and its nomenclature, TSLP is mainly produced in a constitutive manner by epithelial cells, notably by keratinocytes and that of mucosal organs such as the intestine and lungs $(14,15,41,42)$. There is strong evidence suggesting its importance in maintaining barrier integrity in these locations upon infection and inflammation through tissue remodeling and by conditioning dendritic cells (DCs) toward a tolerogenic phenotype. This supports the development of regulatory $\mathrm{T}$ cells and polarization of activated helper $\mathrm{T}$ cells to exhibit type 2 (Th2) characteristics (14-17). Altogether, these findings suggest roles for TSLP that are not only segregated spatially and possibly temporally from that of IL-7 but also serve a unique function in developing immune responses.

\section{ILC SUBSETS AND THEIR ORIGIN}

Terminally differentiated ILCs closely resemble helper T cells, such that a version of a helper ILC mirrors each of Th1, 2, 17 helper $\mathrm{T}$ cells in terms of key transcription factor dependency, cytokine output, and resulting pathologies $(43,44)$. In fact, most of what we have learned about the function and development of ILCs since their discovery has been aided by our knowledge of T cells.

ILCs have been documented and categorized into three general helper ILC groups. Group 1 ILCs (ILC1s) are found in various tissues including the small intestine and liver, are dependent on T-bet and produce the Th1 cytokines IFN- $\gamma$ and TNF- $\alpha(4,45)$. Natural killer (NK) cells are similar to ILC1s but are not considered part of the helper ILC subset and generally do not express the IL-7R $\alpha$ (45). However, some tissue NK cells express a range of IL-7R $\alpha$ levels, like in the thymus, colon, and small intestine lamina propria (siLP) $(46,47)$. Group 2 ILCs (ILC2s) express GATA3 prominently, similar to Th2 cells, and likewise, produce IL-5, IL-13, and in some conditions IL-9 when activated by the alarmins TSLP, IL-33, and IL-25 (6, 48-50). They are also the major ILC subset found in the lungs and play an important role in airway immunity $(51,52)$. Group 3 ILCs (ILC3s) are ROR $\gamma \mathrm{t}$-dependent, like Th17 cells, and consist of a major subset that produces IL-17 and IL-22 in response to IL-23 and are critical for intestinal immunity against pathogens $(1,53)$. Another subset of ILCs are the Lymphoid Tissue inducer cells (LTi), which are also ROR $\gamma$ t-dependent group 3 ILCs, and are considered important for the development of secondary lymphoid organs (54).

In mice, the fetal liver serves as the earliest known source of ILCs where IL-7 is known to be produced and support the development of other lymphoid cells $(5,55)$. The various precursors at different stages of ILC development are primarily studied using mouse models and are classified based on their surface markers and the transcription factors that lead to their lineage restriction. Common lymphoid progenitors (CLPs) are descendants of lymphoid-primed multipotent progenitors (LMPPs) which largely do not express IL-7R $\alpha$ and are the source of all lymphoid cells (56). CLPs can develop into all lymphoid cell progenitor subsets including $\alpha$-lymphoid progenitors ( $\alpha \mathrm{LP})$, early innate lymphoid progenitors (EILPs), and the common helper innate lymphoid precursors (CHILPs) $(57,58)$. $\alpha$ LP and EILPs can develop into all of the known ILC subsets including ILCs 1, 2 and 3 and conventional NK cells (57, 58). These cells are also known as global innate lymphoid progenitors (GILPs). The more restricted precursors, Id $2^{+}$common helper innate lymphoid precursor (CHILPs), can generate all helper ILC subsets (ILC1, 2, 3 and LTi) but not NK cells (4). LTi cells arise from $\mathrm{PLZF}^{-}$precursors while the rest of the helper ILCs 1, 2, and 3 arise from $\mathrm{PLZF}^{+}$innate lymphoid precursors (5). However, it is important to note that a hierarchical model of development is prone to revision based on new studies. The developmental stages and potentials of the various ILC precursors are more nuanced and complex, and can change depending on the organism, age, sex, inflammation, and the tissues examined (55).

When helper ILCs were discovered as a new subset of immune cells and reported to play important roles in immunity, they were described as IL-7R $\alpha^{+}$cells. Aside from being an important defining marker for a major subset of ILCs, IL-7R $\alpha$ is important in mediating IL-7 and TSLP signaling in these cells to promote their development and function.

\section{IL-7R $\alpha$ IN THE DEVELOPMENT OF ILCs IL-7 and ILC Development}

IL-7 is indispensable for the development of all helper ILCs. The role of IL-7 in ILC development was initially discovered in LTi cells. It is now well-established that IL-7 is important for LTi cell development and therefore the architecture of secondary lymphoid organs (59-61) [reviewed in (62).] The more recent discovery of the helper-ILC groups extended the importance of IL-7 to the development of other ILCs. It was first reported that "natural helper" cells (now called ILC2s) associated with the adipose tissue depend on IL-7 to survive and maintain their numbers in the tissue (6). Despite these findings, we have been unaware of how IL-7 instructs the development of ILCs. The recent unveiling of the heterogeneity in ILC precursors and their transcription factor dependency has now led to a better understanding of the factors that mediate the development of ILCs. Nuclear factor IL-3 (NFIL3) is a transcription factor required for NK cell development, and it was more recently found to be critical for the development of all other ILCs (4, 58, 63-66). The expression of NFIL3 in CLPs requires IL-7, which directs STAT5 activation and binding of pSTAT5 to the NFIL3 promoter (63). NFIL3 expression is specifically required for Id2 expression and generation of CHILPs, and hence the development of all helper-ILCs (63). While it is better established that IL-7 controls pan helper-ILC development through control of a common precursor from CLPs to CHILPs, it is less clear how IL-7 controls development of more committed PLZF ${ }^{+}$ILC precursors (ILCPs) from CHILPs. It is known that expression of GATA3 at the CHILP stage is required for the development of ILCPs that give rise to the majority of the ILC lineage (67). Since GATA3 is downstream of STAT5, it is possible that IL-7 signaling is important if not indispensable in the development of ILCPs and their ILC2 progenies through related pathways 
$(68,69)$. In addition to inducing GATA3 in ILC2s, a recent studies have found STAT5 to be a major regulator of ILC homeostasis by regulating multiple networks ranging from survival factors such as Bcl-2 and transcription factors such as T-bet, ROR $\gamma \mathrm{t}$, and Sall3 which each play a role in the function and differentiation of various ILC subsets $(70,71)$ (Figure 2).

In addition to the BM, IL-7 is produced in the fetal liver where earliest progenitors of ILCs can be found (72). Moreover, IL-7 is known to orchestrate the development of lymphoid cells in this tissue (73). IL-7 is also abundant in the thymus where T cells develop from early thymic progenitors (ETPs). Increasing evidence suggests thymic development of ILCs, however, it is unclear to what degree the thymus serves as a source of ILCs and whether ILCs and T cells share the same thymic progenitors. Early studies describe a mouse thymic NK cell subset that expressed the IL-7R $\alpha$ depends on IL-7 for their development and has the capability to seed peripheral tissues (47). These murine thymic NK cells also shared similar characteristics to human $\mathrm{CD}^{+} 6^{+} \mathrm{NK}$ cells (47). More recent studies have shown E-proteins E2A and HEB to be specifiers of T cell commitment in thymic precursors and their deletion leads to a skew toward ILC2 development, suggesting that thymocytes explore multiple fates before commitment $(74,75)$. Furthermore, IL-7R $\alpha$ expression is inversely correlated with the expression of E-proteins in early ILC progenitors in the BM but correlates directly with that of Id2. This suggests an increased dependence on IL-7 for ILC

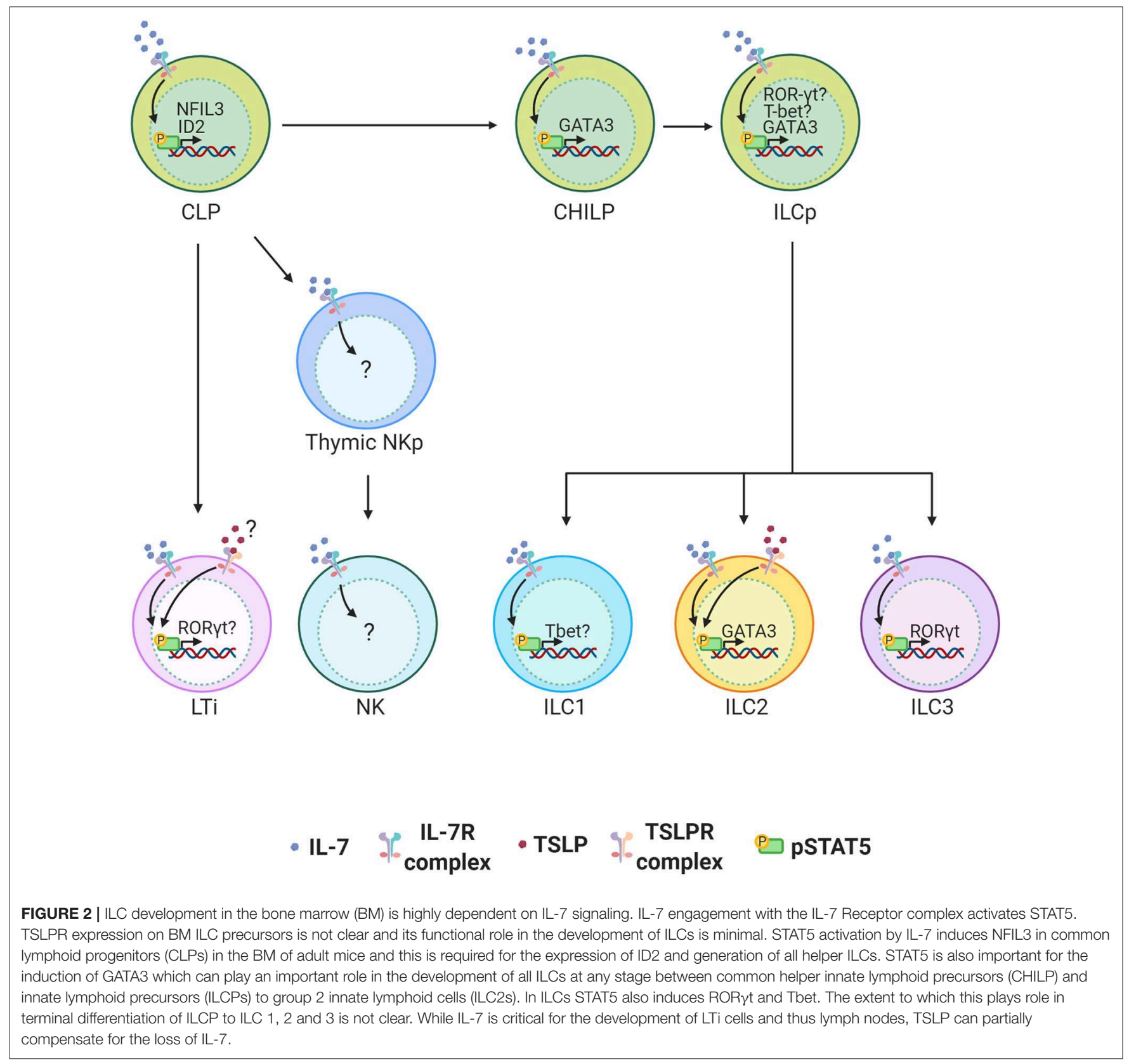


development. To better understand the role of IL-7 in thymic ILC development, it is important that we elucidate its downstream signaling in various ILC precursors in the BM and thymus.

IL-7 has recently been found at the center of ILC differentiation. For instance, the quantity of IL-7 that is available combined with the strength and duration of Notch signaling can dictate the fate of mouse fetal liver derived CLPs (76). Whereas, high IL-7 and medium Notch signaling favors ILC2 and ILC1/NK cell differentiation, low IL-7 and high Notch signaling favors $\mathrm{T}$ cell differentiation in mice (76). The results are however different when human hematopoietic progenitor cells are treated in a similar manner, where IL-7, and Notch signaling induce ILC3 differentiation while suppressing IL-15 induced NK cell differentiation (77). These findings reveal contrasting roles for IL-7 in ILC differentiation which can be explained by differences in mouse and human hematopoiesis and progenitor sources. Further studies are needed to identify other contributing factors that create divergent roles for IL-7.

While IL-7 is clearly crucial to the development of ILCs, other cytokines can partially compensate for IL-7 or drive IL7-independent maintenance of ILCs. For instance, IL-15 (a $\gamma \mathrm{c}$ cytokine) can partially complement IL-7's defects in ILCs in IL-7R $\alpha^{-/-}$mice (46). This is based on a study that found residual ILCs in IL-7R $\alpha^{-/-}$mice express the IL-15R $\beta$ and respond variably to IL-15 in vitro through increased survival depending on the type of ILCs (46). Further assessment of IL$15^{-/-}$, IL-7 $\mathrm{R}^{-/-}$, and IL-7R $\alpha^{-/-}$IL-15 $5^{-/-}$mice revealed IL7 -independent sustenance of ILCs by IL-15 that varied in degrees depending on the type of ILCs and the tissue examined. Most notably, NK cells were normal in numbers in IL-7 R $\alpha^{-/-}$mice but greatly reduced in IL-15 $-/-$ mice as expected (46). However, IL-7R $\alpha^{-/-}$IL-15 $-/-$mice had greater loss of NK cells compared to IL-15 $1-/$ mice, more so in the colon than the siLP. Consistent with this is the higher expression of IL-7R $\alpha$ observed by colon NK cells compared to siLP NK cells. This suggests a supportive role for IL-7 in NK cell development in a tissue specific manner. ILC1s were only marginally reduced in IL-7 R $\alpha^{-/-}$and IL-15 $-/-$ mice compared to WT mice, while IL-7R $\alpha^{-/-}$IL- $15^{-/-}$mice experienced a multi-fold reduction in ILC1s in the colon and the siLP, suggesting a synergistic contribution by both cytokines in development/maintenance of ILC1s (46). While IL-15 ${ }^{-/-}$mice have normal number of $\mathrm{NKp}_{4} 6^{+}$and $\mathrm{CCR}^{+}$ILC3s in the siLP and colon, loss of both IL-7 and IL-15 signaling results in even greater loss of these cells compared to IL-7R $\alpha^{-/-}$mice. Similarly, IL-7R $\alpha^{-/-}$IL-15 $15^{-/}$mice had greater reduction in number of ILC2s in the siLP and colon than IL-7 $\mathrm{R} \alpha^{-/-}$mice. However, IL-7 R $\alpha^{-/-}$and IL-7R $\alpha^{-/-}$IL-15 $5^{-/-}$mice have equal numbers of ILC2Ps suggesting a supportive role for IL-15 in survival of ILC2s in the periphery (46). The subset of ILC2s most affected in IL-7R $\alpha^{-/-}$mice were ST2 ${ }^{+} \mathrm{KLRG}^{+}{ }^{+}$ILC2s while ST2 ${ }^{-}$ILC2s were unaffected. The functional importance of these residual ILC2s has yet to be determined. Since they lack ST2 (IL-33 receptor) and are IL-7R $\alpha$ deficient, they are non-responsive to IL-33, IL-7, and TSLP—the most potent activators of ILC2s - what are the cytokines that activate these cells? Common gamma chain cytokines including IL-7 and IL15 use the $\gamma$ c receptor which relies on Jak3 to transmit signals. Loss or mutation of this receptor leads to loss of multiple ILC subsets in mice and inhibition of Jak3 using tofacitinib abrogates human ILC1 and 3 proliferation and development in vitro (78). Investigating downstream signaling factors can help identify overlapping pathways that are necessary for the development of ILCs.

FLT3 ligand (FLT3L) can also compensate for IL-7 in ILC development (79). IL-7 $-/-$ mice present with normal numbers of NK cells in the small intestine but have reduced ILC2s and ILC3s. Loss of FLT3L depletes all ILCs including NK cells suggesting a role for FLT3 that is earlier than that of IL-7 in ILC development (79). Treatment with rFLT3L for 10 days can restore all ILC populations in of IL-7 ${ }^{-/}$mice except for ILC2s which suggests either a greater dependence on IL-7 by ILC2s or that FLT3L mediated rescue of ILCs occurs at later stages of ILC development, perhaps after commitment to specific groups.

\section{TSLP and ILC Development}

The influence of TSLP in the development of ILCs is minimal, as previous reports using $\mathrm{TSLPR}^{-/-}$mice have shown normal numbers of ILC2s in the lungs (80). This is not surprising since its effect in lymphopoiesis is insubstantial as well. Although loss of TSLP signaling has little effect on lymphopoiesis, addition of TSLP to in vitro cultures can enhance mouse and human B cell as well as mouse $\mathrm{T}$ cell expansion from hematopoietic progenitors sourced from fetal liver $(37,81-83)$. It is however, unclear if ILC progenitors express the TSLPR and if significant levels of TSLP are produced in the fetal liver and bone marrow.

Both IL-7 and TSLP use the IL-7R $\alpha$ but the increased importance that IL-7 has compared to TSLP in lymphoid development may stem from the increased binding affinity of IL7 to its receptors, or more likely due to the established importance of $\gamma$ c/Jak3 in ILC development. Understanding how well TSLPR and/or Jak2 facilitate ILC development will be important to make a definitive statement.

Most studies of TSLP are in the context of ILC2s since no other ILCs have been reported to express the receptor for TSLP. Nonetheless, ILC research is in its preliminary stages and identification of the transcriptional dependencies of the various ILC subsets is in progress. It is possible that TSLP can mediate aspects of ILC development through unidentified pathways that are possibly masked by our current method of grouping ILCs. Supporting this hypothesis, over expression of TSLP has been shown to support the development of LTis in a compensatory manner in IL-7-deficient mice (61) (Figure 2). It is unknown whether these effects by TSLP are direct or indirect. Since the manipulation of TSLP and/or IL-7 signaling is integral for drugs that treat several conditions including allergies, cancers and infectious diseases, it is important that we have a better understanding of the interplay between the two cytokines in ILC development to design more efficient drug treatments $(18,84)$.

\section{IL-7R $\alpha$ IN ILC HOMEOSTASIS AND FUNCTION}

\section{IL-7 and ILC Function}

While studies on IL-7's developmental roles in ILCs are substantial, research in its effector functions are relatively modest. Indeed, IL-7 was considered an important factor for the 
development of T cells long before its role in effector functions was examined. IL-7 is mainly produced in primary lymphoid tissues such as the bone marrow and thymic stromal cells where immune cell development occurs $(26,85)$. However, this cytokine is also produced in secondary lymphoid organs and can be induced in skin, lung, intestinal epithelial cells, and liver as shown by fluorescence microscopy of IL-7 reporter mice and ELISA $(28,29,32,85,86)$. The extent of our knowledge on IL-7 and ILC function is based on a series of in vitro experiments.

IL-7 alone or with IL-33 can stimulate the production of Th2 cytokines, IL-5 and IL-13, from murine ILC2s (6, 48, 50, 87) (Figure 3). These Th2 cytokines are important factors produced by ILC2s that promote helminth expulsion, antiviral effects, and tissue repair. A recent study showed that mice lacking T-bet had increased number of ILC2s and production of IL-5 and IL-13 leading to enhanced worm clearance during a Trichinella spiralis infection (88). This activity in ILC2s correlated with higher expression of IL-7R $\alpha$ leading to increased activation of STAT5 (88). This suggests that T-bet is a regulator of IL-7R $\alpha$ expression, and that IL-7 may enhance ILC2 function (88). This necessitates further in vivo examination of the role of IL-7 in ILC2 function.

ROR $\gamma t^{+}$ILC3 derived IL-22 plays an important role in defense and regulation of pathogenic and non-pathogenic bacteria in the intestine by maintaining barrier integrity and inducing anti-microbial peptide expression by epithelial cells such as RegIII $\gamma$ and RegIII $\beta$ (89-91). ROR $\gamma \mathrm{t}^{+}$ILC3s can however lose these abilities and differentiate into $\mathrm{ROR} \gamma \mathrm{t}^{-}$cells through stimulation with IL-12 and IL-15 (92). This leads to their conversion from IL-22 producing ILC3s to IFN- $\gamma$ producing ILC1-like cells. Together with the microbiota, IL-7 is able to counteract this transition by stabilizing ROR $\gamma \mathrm{t}$ expression (92) (Figure 4). IL-23 is the key cytokine responsible for ROR $\gamma \mathrm{t}$ mediated IL-22 production by ILC3s (93). This finding suggests that IL-7 may in part be important for maintaining the IL22 production status in ILC3s, which is pivotal for host defense and barrier integrity during bacterial infection. Indeed, IL-7 stimulation can induce ROR $\gamma \mathrm{t}$ expression and play a supportive role in IL-23 mediated IL-22 production in ILC3s (94). Furthermore, in vitro co-culture of IL-7 producing mesenchymal stromal cells (MSCs) with ILC3s led to IL-22 production and enhanced IL-2 induced proliferation of ILC3s (95). This was due to IL-7 derived from MSCs as measured by ELISA (95).

IL-7, together with retinoic acid (RA), is also important for homing of ILCs to gut-associated tissues by upregulating ILC3-intrinsic expression of $\alpha 4 \beta 7$ and selectin ligands, an effect mediated by IL-7 in T cell homing as well $(96,97)$ (Figure 4). Interestingly, IL-7 is also required for survival of ILC3s in the LN post-development, which in turn is important for homing naïve T cells to lymphoid tissues (98). It should be noted however, that while the RA/IL-7 axis has a positive effect on ILC3s, treatment with RA reduces IL-7R $\alpha$ expression in ILC2s and ILC2Ps and this leads to reduced numbers of ILC2s possibly through reduced survival, homing or development (99) (Figure 4). Taken together, IL-7 plays diverse roles in dictating ILC function but new approaches are necessary to clarify them and clearly distinguish them from IL-7's developmental roles.

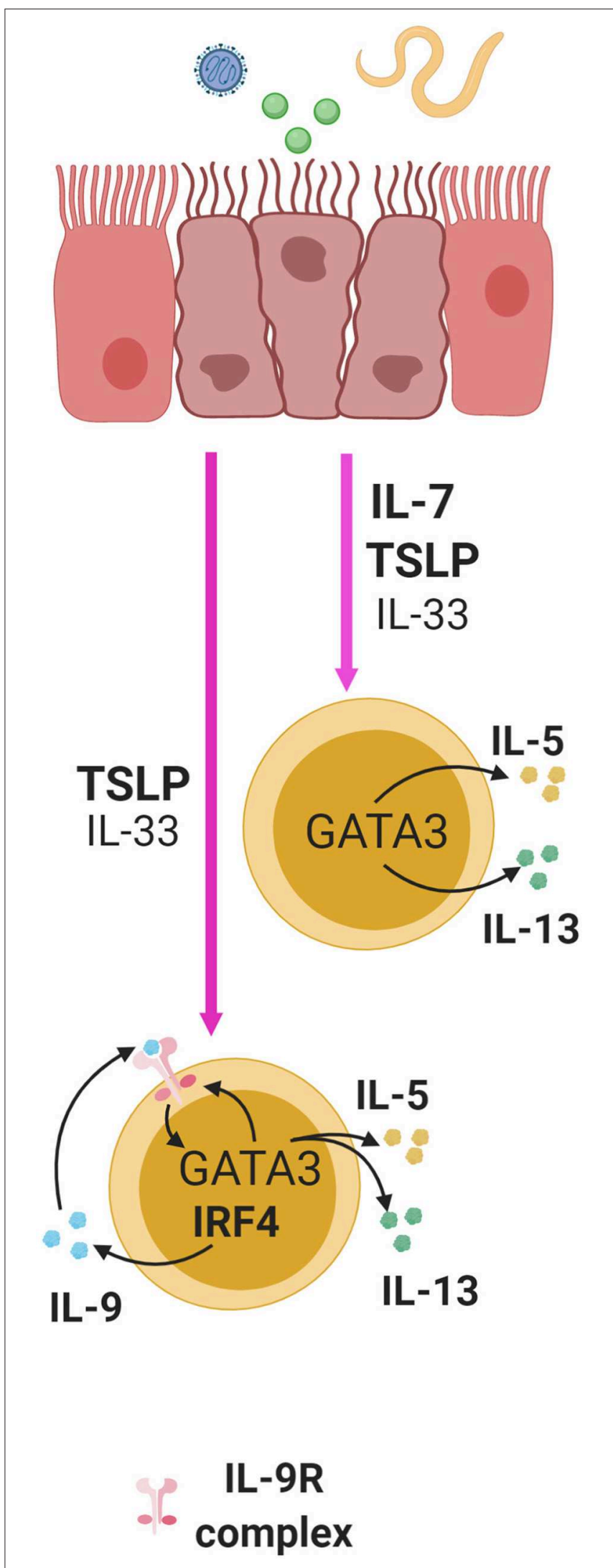

FIGURE 3 | Continued 
FIGURE 3 | ILC2s in the lung, small intestine, and skin are activated by alarmins following exposure to virus, helminthes, or allergens and this induces cytokine production in ILC2s. IL-7 and TSLP significantly enhance the effect of IL-33 in multiple mucosal sites. TSLP and IL-33 synergistically induce the expression of IL-9 in an IRF4 dependent manner in ILC2s. Through autocrine signaling, this can enhance the production of IL-5 and IL- 13 and IL-9R in a GATA3 dependent manner, thus creating a positive feedback loop to further enhance cytokine production.

\section{TSLP in ILC2 Function}

TSLP, along with IL-33 and IL-25, are produced by mucosal epithelial cells, and as alarmins, these cytokines are important activators of immune responses. Stimulation of lung epithelial cells with virus, allergens or helminths can lead to enhanced production of TSLP, IL-33 and IL-25, and stimulation of lung ILC2s with TSLP alone or in combination with IL33 can induce IL-4, IL-5 and IL-13 secretion (48-50, 80). Interestingly, while IL-33 alone is able to induce such secretion in vitro, adding small doses of TSLP to the stimulation cocktail is sufficient to significantly enhance the secretory program, indicating its potency (50) (Figure 3). Furthermore, TSLP is able to mediate skin inflammation through ILC2s in mice independent of IL-33 and IL-25 (100). In summary, TSLP can greatly enhance ILC2 responses with or without help from IL-33 and IL-25.

\section{The TSLP-GATA3 Axis in ILC2 Function and Homeostasis}

TSLP can activate multiple signaling pathways in $\mathrm{T}$ cells and ILC2s alike. In T cells, TSLP as well as IL-7, are able to activate STAT5 signaling which activates pro-survival signals mediated by Bcl-2 (40). Similarly, ILC2s respond to TSLP by activating STAT5, and this triggers IL-13 production (68). The transcription factor GATA3 is indispensable for the development of all ILCs, an important identifying marker for ILC2s, and a direct target of STAT5 $(67,68)$. In addition, TSLP can induce GATA3 in ILC2s which in turn mediates IL-4, IL-5 and IL-13 production in vitro in these cells, and silencing GATA3 alone greatly reduces this TSLP response (68). This signifies the importance of GATA3 for TSLP-mediated ILC2 function. Interestingly, GATA3 induction can lead to enhanced expression of TSLPR and IL-33 receptor (ST2) which suggests that TSLP signaling through GATA3 can enhance responsiveness to IL-33 and TSLP (68). This model is consistent with studies that have suggested TSLP and IL-33 having synergistic effects on ILC2s (50). Moreover, GATA3 can directly bind to exon 2 of the gene encoding IL-7R $\alpha$ and induce its expression thus enhancing IL-7 and TSLP signaling (101). Altogether, assuming linearity, this suggests a positive feedback loop whereby TSLP and GATA3 signaling rely on each other to amplify early innate responses by relatively rare cells in an environment with limited cytokine availability.

\section{TSLP in Support of IL-9 Programming of ILC2 Function}

ILC2s can produce IL-9 in response to TSLP in a manner dependent on the transcription factor interferon regulatory factor 4 (IRF4) (50). IL-9 derived from ILC2s can also serve to enhance early ILC2 responses by signaling in an autocrine fashion to increase IL-5 and IL-13 production during helminth infection in mice with Nippostrongylus brasiliensis (Figure 3). This subsequently promotes the expression of genes important for mucus production and tissue repair in lung epithelial cells $(50,102)$. Additionally, IL-9 receptor expression has been found to be positively regulated by GATA3 through RNA-sequencing transcriptomic analysis of ILC2s (67). Since TSLP can induce GATA3 expression in ILC2s, this suggests that TSLP may shape ILC2 responses through control of IL-9 receptor and ligand expression (68) (Figure 3). This further demonstrates that TSLP can act through multiple pathways in regulating ILC2 function.

\section{The Dark Side: TSLP Duality}

Notwithstanding its importance at barrier sites, TSLP is wellestablished as an inducer of Th2 cytokine driven allergic inflammation such as atopic dermatitis, eosinophilic esophagitis, asthma and allergic rhinitis, all mediated by a variety of cells including eosinophils, basophils, and ILC2s (16, 48, 100, 103, 104). TSLP supports the production of IL- 5 and IL- 13 by lung ILC2s, which contributes to eosinophilia and elevated mucus production in papain and chitin models of allergy induction $(48,50)$. Corticosteroids are a common treatment for asthma, but TSLP can enhance the survival and proliferation of IL-13 ${ }^{+}$ILC2s through STAT5 activation, thus limiting therapeutic effectiveness (105-107). Similarly, respiratory syncytial virus (RSV) infection in mice induces airway hyper responsiveness (AHR) and airway obstruction, characterized by enhanced ILC2 proliferation and production of IL-13, and this effect is significantly reduced in TSLPR-deficient mice (49). Interestingly, TSLPR protein expression can be upregulated in ILC2s early during RSV infection. Proliferating ILC2s that produce IL-13 (but not IL-5) had higher expression of TSLPR mRNA and protein. (49). This differential expression by subpopulations of ILC2s may explain how TSLP can have both beneficial and detrimental effects on ILC2s. Nonetheless, comparative analysis of AHR, allergy, and infection models is necessary for a definitive statement.

There are other circumstances that can lead to duality in TSLP's effect on ILC2s or other TSLPR expressing cells. Relevant clinical studies have implicated the over-production of TSLP, either due to mutation(s) or constant exposure to allergen(s), as the main culprit in TSLP-mediated allergic inflammation $(108,109)$. Another model suggests that TSLP may have diverse roles due to the presence of two transcript variants for TSLP producing a long and short isoforms (110, 111). The short isoform of TSLP is expressed constitutively during homeostasis and is important for anti-inflammatory, barrier integrity and anti-microbial responses, while the long isoform is expressed during inflammation and supports inflammatory cytokine production $(110,111)$. Lastly, it is possible that the combined effects of other cytokines in the environment with TSLP can influence the outcomes, and these varying compositions may define a certain threshold. One or more of these scenarios may occur simultaneously making 

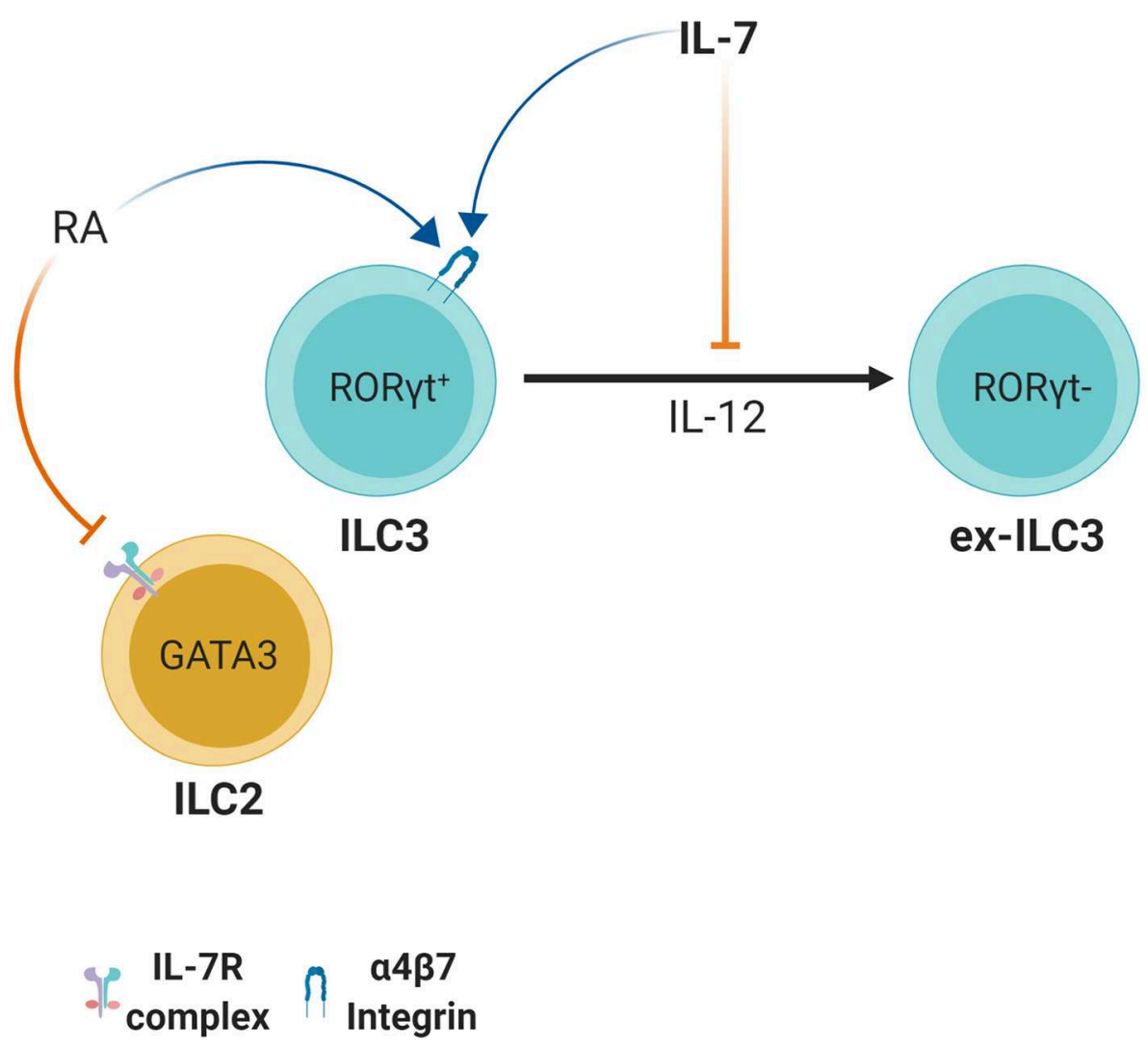

FIGURE 4 | Retinoic acid and IL-7 induce the expression of the gut homing receptor integrin $\alpha 4 \beta 7$. However, in ILC2s, retinoic acid causes downregulation of IL-7R $\alpha$. ILC3s appear to have plasticity since stimulation with IL-12 leads to conversion to ILC1-like ex-ILC3s. Aided by microbial stimulation, IL-7 induces or stabilizes RORyt expression and maintains the IL-22 production status of ILC3s thus preventing conversion to ILC1-like ex-ILC3s.

multi-faceted approaches a preferred route of treatment for allergic inflammations.

The negative effects of TSLP have been noted in ILC3s as well. In a report, loss of IKK $\alpha$ in murine intestinal epithelial cells (IECs) led to an overproduction of TSLP during Citrobacter rodentium infection (112). This resulted in reduced IL-22 production by ILC3s, impaired bacteria clearance and increased mortality. In vivo blockade of TSLP was sufficient to restore anti-bacterial immunity. The inhibitory effect of TSLP on ILC3 function was confirmed in in vitro experiments. Addition of TSLP impaired the ability of IL-23 to stimulate IL-22 production from ILC3s in bulk splenocyte cultures, however this phenomenon was not seen with sort purified ILCs, suggesting that TSLP acted indirectly. This finding is unprecedented and warrants further investigation to clearly map the connection between TSLP and ILC3s, and provide more insight into their implications in mucosal and barrier health.

\section{CONCLUDING REMARKS}

IL-7R $\alpha$ is a cytokine receptor whose expression is tightly regulated throughout the development and life of lymphoid cells. IL-7 and TSLP signal through IL-7R $\alpha$ and play multiple roles in determining the fate of ILCs and T cells. Since their discovery, research on ILCs have led to great insights in mucosal immunology and lymphoid development. Their resemblance to adaptive lymphoid cells has enabled us to study their biology more efficiently. Despite the current progress, we have yet to fill significant gaps of knowledge in ILC development and function. It is still unclear when commitment to the ILC fate occurs during hematopoiesis and how IL-7 controls this program. The development of ILCs in vivo was found to rely on key transcription factors such as NFIL3 whose activation is dependent on IL-7 signaling. However, without a complete picture of the source of ILCs, it is hard to pinpoint dependencies on any given single cytokine. In addition, recent studies have allowed us to better appreciate the complexity of hematopoiesis, and in doing so, the differences between murine and human lymphopoiesis. Although studies with mouse models have provided great insight in lymphopoiesis, we should be cautious in our interpretations. Recent advances in understanding ILC development can be credited to transcriptomic studies and single cell resolution analysis that have provided a complex view of ILC heterogeneity. Further studies utilizing similar methods can be conducted to identify ILC precursors in lymphoid and non-lymphoid tissues and examine the factors that regulate their development. Multiple studies that have shown a role for IL-7 and TSLP in ILC function have 
used in vitro treatment with cytokines. While these studies have provided great insights on how these cytokines can influence ILCs, it is important to validate and extend these findings through various transgenic animal models to reveal any physiologically relevant and indispensable roles of IL-7 and TSLP in ILC biology.

\section{AUTHOR CONTRIBUTIONS}

AS reviewed the literature and wrote the manuscript, edited it and generated the figures. NA reviewed the drafts, provided critical input and edited the text and figures.

\section{REFERENCES}

1. Spits H, Artis D, Colonna M, Diefenbach A, Di Santo JP, Eberl G, et al. Innate lymphoid cells-a proposal for uniform nomenclature. Nat Rev Immunol. (2013) 13:145-9. doi: 10.1038/nri3365

2. Kondo M, Weissman IL, Akashi K. Identification of clonogenic common lymphoid progenitors in mouse bone marrow. Cell. (1997) 91:661-72. doi: 10.1016/S0092-8674(00)80453-5

3. Wong SH, Walker JA, Jolin HE, Drynan LF, Hams E, Camelo A, et al. Transcription factor ROR[alpha] is critical for nuocyte development. Nat Immunol. (2012) 13:229-36. doi: 10.1038/ni.2208

4. Klose Christoph SN, Flach M, Möhle L, Rogell L, Hoyler T, Ebert K, et al. Differentiation of type 1 ILCs from a common progenitor to all helper-like innate lymphoid cell lineages. Cell. (2014) 157:340-56. doi: 10.1016/j.cell.2014.03.030

5. Constantinides MG, McDonald BD, Verhoef PA, Bendelac A. A committed precursor to innate lymphoid cells. Nature. (2014) 508:397-401. doi: 10.1038/nature13047

6. Moro K, Yamada T, Tanabe M, Takeuchi T, Ikawa T, Kawamoto $\mathrm{H}$, et al. Innate production of $\mathrm{T}(\mathrm{H}) 2$ cytokines by adipose tissueassociated c-Kit(+)Sca-1(+) lymphoid cells. Nature. (2010) 463:540-4. doi: $10.1038 /$ nature 08636

7. Satoh-Takayama N, Lesjean-Pottier S, Vieira P, Sawa S, Eberl G, Vosshenrich CAJ, et al. IL-7 and IL-15 independently program the differentiation of intestinal CD3(-)NKp46(+) cell subsets from Id2-dependent precursors. $J$ Exp Med. (2010) 207:273-80. doi: 10.1084/jem.20092029

8. Mazzucchelli RI, Riva A, Durum SK. The human IL-7 receptor gene: deletions, polymorphisms and mutations. Semin Immunol. (2012) 24:22530. doi: 10.1016/j.smim.2012.02.007

9. Patton DT, Plumb AW, Redpath SA, Osborne LC, Perona-Wright G, Abraham N. The development and survival but not function of follicular B cells is dependent on IL-7R $\alpha$ Tyr449 signaling. PLoS ONE. (2014) 9:e88771. doi: 10.1371/journal.pone.0088771

10. Pellegrini M, Calzascia T, Elford AR, Shahinian A, Lin AE, Dissanayake D, et al. Adjuvant IL-7 antagonizes multiple cellular and molecular inhibitory networks to enhance immunotherapies. Nat Med. (2009) 15:52836. doi: $10.1038 / \mathrm{nm} .1953$

11. Pellegrini M, Calzascia T, Toe JG, Preston SP, Lin AE, Elford AR, et al. IL-7 engages multiple mechanisms to overcome chronic viral infection and limit organ pathology. Cell. (2011) 144:601-13. doi: 10.1016/j.cell.2011.01.011

12. Osborne LC, Dhanji S, Snow JW, Priatel JJ, Ma MC, Miners $\mathrm{MJ}$, et al. Impaired CD8 $\mathrm{T}$ cell memory and CD4 $\mathrm{T}$ cell primary responses in IL-7R alpha mutant mice. J Exp Med. (2007) 204:619-31. doi: $10.1084 /$ jem.20061871

13. Plumb AW, Patton DT, Seo JH, Loveday E-K, Jean F, Ziegler SF, et al. Interleukin-7, but not thymic stromal lymphopoietin, plays a key role in the $\mathrm{T}$ cell response to influenza A virus. PLoS ONE. (2012) 7:e50199. doi: 10.1371/journal.pone.0050199

\section{FUNDING}

Work in the laboratory was supported by a grant to NA from the Canadian Institutes for Health Research (MOP-126060 and PJT-156119). AS was supported by the John Richard Turner Fellowship.

\section{ACKNOWLEDGMENTS}

We would like to acknowledge Dr. Lisa Osborne, Julia Lu, and Etienne Melese at the University of British Columbia for their critical revision of this manuscript. All figures were made in (C)BioRender - biorender.com.

14. Soumelis V, Reche PA, Kanzler H, Yuan W, Edward G, Homey B, et al. Human epithelial cells trigger dendritic cell-mediated allergic inflammation by producing TSLP. Nat Immunol. (2002) 3:673-80. doi: 10.1038/ni805

15. Taylor BC, Zaph C, Troy AE, Du Y, Guild KJ, Comeau MR, et al. TSLP regulates intestinal immunity and inflammation in mouse models of helminth infection and colitis. J Exp Med. (2009) 206:655-67. doi: 10.1084/jem.20081499

16. Ziegler SF, Roan F, Bell BD, Stoklasek TA, Kitajima M, Han H. The biology of thymic stromal lymphopoietin (TSLP). Adv Pharmacol. (2013) 66:129-55. doi: 10.1016/B978-0-12-404717-4.00004-4

17. Ziegler SF, Artis D. Sensing the outside world: TSLP regulates barrier immunity. Nat Immunol. (2010) 11:289-93. doi: 10.1038/ni.1852

18. Buckley RH. Molecular defects in human severe combined immunodeficiency and approaches to immune reconstitution. Ann Rev Immunol. (2004) 22:625-55. doi: 10.1146/annurev.immunol.22.012703.104614

19. Kondo M, Takeshita T, Higuchi M, Nakamura M, Sudo T, Nishikawa S, et al. Functional participation of the IL-2 receptor gamma chain in IL-7 receptor complexes. Science. (1994) 263:1453-4. doi: 10.1126/science.8128231

20. Verstraete K, van Schie L, Vyncke L, Bloch Y, Tavernier J, Pauwels E, et al. Structural basis of the proinflammatory signaling complex mediated by TSLP. Nat Struct Mol Biol. (2014) 21:375-82. doi: 10.1038/nsmb.2794

21. Gonnord P, Angermann BR, Sadtler K, Gombos E, Chappert P, MeierSchellersheim M, et al. A hierarchy of affinities between cytokine receptors and the common gamma chain leads to pathway cross-talk. Sci Signal. (2018) 11:eaal1253. doi: 10.1126/scisignal.aal1253

22. Patton DT, Plumb AW, Abraham N. The survival and differentiation of pro$\mathrm{B}$ and pre-B cells in the bone marrow is dependent on IL-7R $\alpha$ Tyr449. J Immunol. (2014) 193:3446-55. doi: 10.4049/jimmunol.1302925

23. Plumb AW, Sheikh A, Carlow DA, Patton DT, Ziltener HJ, Abraham N. Interleukin-7 in the transition of bone marrow progenitors to the thymus. Immunol Cell Biol. (2017) 95:916-24. doi: 10.1038/icb.2017.68

24. Munitic I, Williams JA, Yang Y, Dong B, Lucas PJ, El Kassar N, et al. Dynamic regulation of IL-7 receptor expression is required for normal thymopoiesis. Blood. (2004) 104:4165. doi: 10.1182/blood-2004-06-2484

25. Hong C, Luckey MA, Park J-H. Intrathymic IL-7: the where, when, and why of IL-7 signaling during T cell development. Semin Immunol. (2012) 24:151-8. doi: 10.1016/j.smim.2012.02.002

26. Mazzucchelli RI, Warming S, Lawrence SM, Ishii M, Abshari M, Washington $\mathrm{AV}$, et al. Visualization and identification of IL-7 producing cells in reporter mice. PLoS ONE. (2009) 4:e7637. doi: 10.1371/journal.pone.0007637

27. Martin CE, Spasova DS, Frimpong-Boateng K, Kim HO, Lee M, Kim KS, et al. Interleukin-7 availability is maintained by a hematopoietic cytokine sink comprising innate lymphoid cells and T cells. Immunity. (2017) 47:171-82 e4. doi: 10.1016/j.immuni.2017.07.005

28. Sawa Y, Arima Y, Ogura H, Kitabayashi C, Jiang J-J, Fukushima T, et al. Hepatic interleukin-7 expression regulates $\mathrm{T}$ cell responses. Immunity. (2009) 30:447-57. doi: 10.1016/j.immuni.2009.01.007 
29. Adachi T, Kobayashi T, Sugihara E, Yamada T, Ikuta K, Pittaluga $S$, et al. Hair follicle-derived IL-7 and IL-15 mediate skin-resident memory T cell homeostasis and lymphoma. Nat Med. (2015) 21:1272-9. doi: $10.1038 / \mathrm{nm} .3962$

30. Watanabe M, Ueno Y, Yajima T, Okamoto S, Hayashi T, Yamazaki M, et al. Interleukin 7 transgenic mice develop chronic colitis with decreased interleukin 7 protein accumulation in the colonic mucosa. J Exp Med. (1998) 187:389-402. doi: 10.1084/jem.187.3.389

31. Shalapour S, Deiser K, Sercan O, Tuckermann J, Minnich K, Willimsky $\mathrm{G}$, et al. Commensal microflora and interferon-gamma promote steadystate interleukin-7 production in vivo. Eur J Immunol. (2010) 40:2391-400. doi: 10.1002/eji.201040441

32. Jin JO, Yu Q. Systemic administration of TLR3 agonist induces IL-7 expression and IL-7-dependent CXCR3 ligand production in the lung. $J$ Leukocyte Biol. (2013) 93:413-25. doi: 10.1189/jlb.0712360

33. Miller CN, Hartigan-O'Connor DJ, Lee MS, Laidlaw G, Cornelissen IP, Matloubian M, et al. IL-7 production in murine lymphatic endothelial cells and induction in the setting of peripheral lymphopenia. Int Immunol. (2013) 25:471-83. doi: 10.1093/intimm/dxt012

34. Dahlgren MW, Jones SW, Cautivo KM, Dubinin A, Ortiz-Carpena JF, Farhat $\mathrm{S}$, et al. Adventitial stromal cells define group 2 innate lymphoid cell tissue niches. Immunity. (2019) 50:707-22 e6. doi: 10.1016/j.immuni.2019.02.002

35. Ray RJ, Furlonger C, Williams DE, Paige CJ. Characterization of thymic stromal-derived lymphopoietin (TSLP) in murine B cell development in vitro. Eur J Immunol. (1996) 26:10-6. doi: 10.1002/eji.1830260103

36. Friend SL, Hosier S, Nelson A, Foxworthe D, Williams DE, Farr A. A thymic stromal cell line supports in vitro development of surface IgM+B cells and produces a novel growth factor affecting B and T lineage cells. Exp Hematol. (1994) 22:321-8.

37. Levin SD, Koelling RM, Friend SL, Isaksen DE, Ziegler SF, Perlmutter RM, et al. Thymic stromal lymphopoietin: a cytokine that promotes the development of IgM+ B cells in vitro and signals via a novel mechanism. J Immunol. (1999) 162:677.

38. Al-Shami A, Spolski R, Kelly J, Fry T, Schwartzberg PL, Pandey A, et al. A role for thymic stromal lymphopoietin in CD4(+) T cell development. J Exp Med. (2004) 200:159-68. doi: 10.1084/jem.20031975

39. Jensen CT, Kharazi S, Boiers C, Cheng M, Lubking A, Sitnicka E, et al. FLT3 ligand and not TSLP is the key regulator of IL-7independent B-1 and B-2 B lymphopoiesis. Blood. (2008) 112:2297-304. doi: 10.1182/blood-2008-04-150508

40. Rochman Y, Kashyap M, Robinson GW, Sakamoto K, Gomez-Rodriguez J, Wagner K-U, et al. Thymic stromal lymphopoietin-mediated STAT5 phosphorylation via kinases JAK1 and JAK2 reveals a key difference from IL-7-induced signaling. Proc Natl Acad Sci USA. (2010) 107:19455-60. doi: $10.1073 /$ pnas. 1008271107

41. Rimoldi M, Chieppa M, Salucci V, Avogadri F, Sonzogni A, Sampietro $\mathrm{GM}$, et al. Intestinal immune homeostasis is regulated by the crosstalk between epithelial cells and dendritic cells. Nat Immunol. (2005) 6:507-14. doi: 10.1038/ni1192

42. Zaph C, Troy AE, Taylor BC, Berman-Booty LD, Guild KJ, Du Y, et al. Epithelial-cell-intrinsic IKK-beta expression regulates intestinal immune homeostasis. Nature. (2007) 446:552-6. doi: 10.1038/nature05590

43. Artis D, Spits H. The biology of innate lymphoid cells. Nature. (2015) 517:293-301. doi: 10.1038/nature14189

44. Kotas ME, Locksley RM. Why innate lymphoid cells? Immunity. (2018) 48:1081-90. doi: 10.1016/j.immuni.2018.06.002

45. Bernink JH, Peters CP, Munneke M, te Velde AA, Meijer SL, Weijer K, et al. Human type 1 innate lymphoid cells accumulate in inflamed mucosal tissues. Nat Immunol. (2013) 14:221-9. doi: 10.1038/ni.2534

46. Robinette ML, Bando JK, Song W, Ulland TK, Gilfillan S, Colonna M. IL15 sustains IL-7R-independent ILC2 and ILC3 development. Nat Commun. (2017) 8:14601. doi: 10.1038/ncomms14601

47. Vosshenrich CA, Garcia-Ojeda ME, Samson-Villeger SI, Pasqualetto V, Enault L, Richard-Le Goff O, et al. A thymic pathway of mouse natural killer cell development characterized by expression of GATA-3 and CD127. Nat Immunol. (2006) 7:1217-24. doi: 10.1038/ni1395

48. Halim Timotheus YF, Krauß Ramona H, Sun Ann C, Takei F. Lung natural helper cells are a critical source of Th2 cell-type cytokines in protease allergen-induced airway inflammation. Immunity. (2012) 36:45163. doi: 10.1016/j.immuni.2011.12.020

49. Stier MT, Bloodworth MH, Toki S, Newcomb DC, Goleniewska K, Boyd KL, et al. Respiratory syncytial virus infection activates IL-13-producing group 2 innate lymphoid cells through thymic stromal lymphopoietin. J Allergy Clin Immunol. (2016) 138:814-24.e11. doi: 10.1016/j.jaci.2016.01.050

50. Mohapatra A, Van Dyken SJ, Schneider C, Nussbaum JC, Liang HE, Locksley RM. Group 2 innate lymphoid cells utilize the IRF4-IL-9 module to coordinate epithelial cell maintenance of lung homeostasis. Mucosal Immunol. (2016) 9:275-86. doi: 10.1038/mi.2015.59

51. Monticelli LA, Sonnenberg GF, Abt MC, Alenghat T, Ziegler CGK, Doering TA, et al. Innate lymphoid cells promote lung tissue homeostasis following acute influenza virus infection. Nat Immunol. (2011) 12:1045-54 doi: 10.1038/ni.2131

52. Chang YJ, Kim HY, Albacker LA, Baumgarth N, McKenzie AN, Smith $\mathrm{DE}$, et al. Innate lymphoid cells mediate influenza-induced airway hyperreactivity independently of adaptive immunity. Nat Immunol. (2011) 12:6318. doi: 10.1038/ni.2045

53. Buonocore S, Ahern PP, Uhlig HH, Ivanov II, Littman DR, Maloy $\mathrm{KJ}$, et al. Innate lymphoid cells drive interleukin-23-dependent innate intestinal pathology. Nature. (2010) 464:1371-5. doi: 10.1038/nature 08949

54. Cupedo T, Crellin NK, Papazian N, Rombouts EJ, Weijer K, Grogan JL, et al. Human fetal lymphoid tissue-inducer cells are interleukin 17-producing precursors to RORC+ CD127+ natural killer-like cells. Nat Immunol. (2009) 10:66-74. doi: 10.1038/ni.1668

55. Schneider C, Lee J, Koga S, Ricardo-Gonzalez RR, Nussbaum JC, Smith LK, et al. Tissue-resident group 2 innate lymphoid cells differentiate by layered ontogeny and in situ perinatal priming. Immunity. (2019) 50:1425-38 e5. doi: 10.1016/j.immuni.2019.04.019

56. Rothenberg EV. Transcriptional control of early $\mathrm{T}$ and $\mathrm{B}$ cell developmental choices. Ann Rev Immunol. (2014) 32:283-321. doi: 10.1146/annurev-immunol-032712-100024

57. Yang Q, Li F, Harly C, Xing S, Ye L, Xia X, et al. TCF-1 upregulation identifies early innate lymphoid progenitors in the bone marrow. Nat Immunol. (2015) 16:1044-50. doi: 10.1038/ni.3248

58. Yu X, Wang Y, Deng M, Li Y, Ruhn KA, Zhang CC, et al. The basic leucine zipper transcription factor NFIL3 directs the development of a common innate lymphoid cell precursor. eLife. (2014) 3:e04406. doi: 10.7554/eLife.04406

59. Yoshida H, Honda K, Shinkura R, Adachi S, Nishikawa S, Maki K, et al. IL-7 receptor $\alpha+$ CD3- cells in the embryonic intestine induces the organizing center of Peyer's patches. Int Immunol. (1999) 11:643-55. doi: 10.1093/intimm/11.5.643

60. Yoshida H, Kawamoto H, Santee SM, Hashi H, Honda K, Nishikawa $\mathrm{S}$, et al. Expression of $\alpha 4 \beta 7$ integrin defines a distinct pathway of lymphoid progenitors committed to $\mathrm{T}$ cells, fetal intestinal lymphotoxin producer, NK, and dendritic cells. J Immunol. (2001) 167:2511-21. doi: 10.4049/jimmunol.167.5.2511

61. Chappaz S, Finke D. The IL-7 signaling pathway regulates lymph node development independent of peripheral lymphocytes. J Immunol. (2010) 184:3562-9. doi: 10.4049/jimmunol.0901647

62. Vonarbourg C, Diefenbach A. Multifaceted roles of interleukin-7 signaling for the development and function of innate lymphoid cells. Semin Immunol. (2012) 24:165-74. doi: 10.1016/j.smim.2012.03.002

63. Xu W, Domingues Rita G, Fonseca-Pereira D, Ferreira M, Ribeiro H, Lopez-Lastra S, et al. NFIL3 orchestrates the emergence of common helper innate lymphoid cell precursors. Cell Rep. (2015) 10:2043-54. doi: 10.1016/j.celrep.2015.02.057

64. Seillet C, Rankin LC, Groom JR, Mielke LA, Tellier J, Chopin M, et al. Nfil3 is required for the development of all innate lymphoid cell subsets. J Exp Med. (2014) 211:1733-40. doi: 10.1084/jem.20140145

65. Geiger TL, Abt MC, Gasteiger G, Firth MA, O’Connor MH, Geary CD, et al. Nfil3 is crucial for development of innate lymphoid cells and host protection against intestinal pathogens. J Exp Med. (2014) 211:1723-31. doi: 10.1084/jem.20140212

66. Gascoyne DM, Long E, Veiga-Fernandes H, de Boer J, Williams O, Seddon $\mathrm{B}$, et al. The basic leucine zipper transcription factor E4BP4 is essential 
for natural killer cell development. Nat Immunol. (2009) 10:1118-24. doi: 10.1038/ni.1787

67. Yagi R, Zhong C, Northrup Daniel L, Yu F, Bouladoux N, Spencer S, et al. The transcription factor GATA3 is critical for the development of all IL-7R $\alpha$-expressing innate lymphoid cells. Immunity. (2014) 40:378-88. doi: 10.1016/j.immuni.2014.01.012

68. Mjösberg J, Bernink J, Golebski K, Karrich Julien J, Peters Charlotte P, Blom B, et al. The transcription factor GATA3 is essential for the function of human type 2 innate lymphoid cells. Immunity. (2012) 37:649-59. doi: 10.1016/j.immuni.2012.08.015

69. Kitajima M, Lee H-C, Nakayama T, Ziegler SF. TSLP enhances the function of helper type 2 cells. Eur J Immunol. (2011) 41:1862-71. doi: 10.1002/eji.201041195

70. Villarino AV, Sciumè G, Davis FP, Iwata S, Zitti B, Robinson GW, et al. Subset- and tissue-defined STAT5 thresholds control homeostasis and function of innate lymphoid cells. J Exp Med. (2017) 214:2999-3014. doi: 10.1084/jem.20150907

71. Liu B, Ye B, Zhu X, Huang G, Yang L, Zhu P, et al. IL-7R $\alpha$ glutamylation and activation of transcription factor Sall3 promote group 3 ILC development. Nat Commun. (2017) 8:231. doi: 10.1038/s41467-017-00235-x

72. Tsuda S, Rieke S, Hashimoto Y, Nakauchi H, Takahama Y. Il-7 supports D-J but not V-DJ rearrangement of TCR-beta gene in fetal liver progenitor cells. J Immunol. (1996) 156:3233.

73. Gunji Y, Sudo T, Suda J, Yamaguchi Y, Nakauchi H, Nishikawa S, et al. Support of early B-cell differentiation in mouse fetal liver by stromal cells and interleukin-7. Blood. (1991) 77:2612-7. doi: 10.1182/blood.V77.12.2612.2612

74. Miyazaki M, Miyazaki K, Chen K, Jin Y, Turner J, Moore AJ, et al. The E-Id protein axis specifies adaptive lymphoid cell identity and suppresses thymic innate lymphoid cell development. Immunity. (2017) 46:818-34.e4. doi: 10.1016/j.immuni.2017.04.022

75. Wang D, Claus CL, Vaccarelli G, Braunstein M, Schmitt TM, ZunigaPflucker JC, et al. The basic helix-loop-helix transcription factor HEBAlt is expressed in pro-T cells and enhances the generation of T cell precursors. $J$ Immunol. (2006) 177:109-19. doi: 10.4049/jimmunol.177.1.109

76. Koga S, Hozumi K, Hirano KI, Yazawa M, Terooatea T, Minoda A, et al. Peripheral PDGFRalpha(+)gp38(+) mesenchymal cells support the differentiation of fetal liver-derived ILC2. J Exp Med. (2018) 215:1609-26. doi: 10.1084/jem.20172310

77. Kyoizumi S, Kubo Y, Kajimura J, Yoshida K, Hayashi T, Nakachi K, et al. Fate decision between group 3 innate lymphoid and conventional NK cell lineages by notch signaling in human circulating hematopoietic progenitors. J Immunol. (2017) 199:2777. doi: 10.4049/jimmunol.1601711

78. Robinette ML, Cella M, Telliez JB, Ulland TK, Barrow AD, Capuder K, et al. Jak3 deficiency blocks innate lymphoid cell development. Mucosal Immunol. (2018) 11:50-60. doi: 10.1038/mi.2017.38

79. Baerenwaldt A, von Burg N, Kreuzaler M, Sitte S, Horvath E, Peter A, et al. Flt3 ligand regulates the development of innate lymphoid cells in fetal and adult mice. J Immunol. (2016) 196:2561. doi: 10.4049/jimmunol.1501380

80. Van Dyken SJ, Mohapatra A, Nussbaum JC, Molofsky AB, Thornton EE, Ziegler SF, et al. Chitin activates parallel immune modules that direct distinct inflammatory responses via innate lymphoid type 2 and gammadelta $\mathrm{T}$ cells. Immunity. (2014) 40:414-24. doi: 10.1016/j.immuni.2014.02.003

81. Vosshenrich CA, Cumano A, Muller W, Di Santo JP, Vieira P. Thymic stromal-derived lymphopoietin distinguishes fetal from adult B cell development. Nat Immunol. (2003) 4:773-9. doi: 10.1038/ni956

82. Scheeren FA, van Lent AU, Nagasawa M, Weijer K, Spits H, Legrand N, et al. Thymic stromal lymphopoietin induces early human B-cell proliferation and differentiation. Eur J Immunol. (2010) 40:955-65. doi: 10.1002/eji.200939419

83. Jiang $\mathrm{Q}$, Coffield VM, Kondo M, Su L. TSLP is involved in expansion of early thymocyte progenitors. BMC Immunol. (2007) 8:11. doi: $10.1186 / 1471-2172-8-11$

84. Corren J, Parnes JR, Wang L, Mo M, Roseti SL, Griffiths JM, et al. Tezepelumab in Adults with Uncontrolled Asthma. N Engl J Med. (2017) 377:936-46. doi: 10.1056/NEJMoa1704064

85. Hara $\mathrm{T}$, Shitara $\mathrm{S}$, Imai $\mathrm{K}$, Miyachi $\mathrm{H}$, Kitano $\mathrm{S}$, Yao $\mathrm{H}$, et al. Identification of IL-7-producing cells in primary and secondary lymphoid organs using IL-7-GFP knock-in mice. J Immunol. (2012) 189:1577-84. doi: $10.4049 /$ jimmunol.1200586
86. Zhang W, Du J-Y, Yu Q, Jin J-O. IL-7 produced by intestinal epithelial cells in response to citrobacter rodentium infection plays a major role in the innate immunity against this pathogen. Infect Immun. (2015) 83:3213-23. doi: 10.1128/IAI.00320-15

87. Neill DR, Wong SH, Bellosi A, Flynn RJ, Daly M, Langford TKA, et al. Nuocytes represent a new innate effector leukocyte that mediates type-2 immunity. Nature. (2010) 464:1367-70. doi: 10.1038/nature08900

88. Garrido-Mesa N, Schroeder JH, Stolarczyk E, Gallagher AL, Lo JW, Bailey $\mathrm{C}$, et al. T-bet controls intestinal mucosa immune responses via repression of type 2 innate lymphoid cell function. Mucosal Immunol. (2019) 12:51-63. doi: 10.1038/s41385-018-0092-6

89. Lindemans CA, Calafiore M, Mertelsmann AM, O'Connor MH, Dudakov JA, Jenq RR, et al. Interleukin-22 promotes intestinal-stem-cell-mediated epithelial regeneration. Nature. (2015) 528:560. doi: 10.1038/nature16460

90. Zeng B, Shi S, Ashworth G, Dong C, Liu J, Xing F. ILC3 function as a doubleedged sword in inflammatory bowel diseases. Cell Death Dis. (2019) 10:315. doi: 10.1038/s41419-019-1540-2

91. Guo X, Qiu J, Tu T, Yang X, Deng L, Anders RA, et al. Induction of innate lymphoid cell-derived interleukin-22 by the transcription factor STAT3 mediates protection against intestinal infection. Immunity. (2014) 40:25-39. doi: 10.1016/j.immuni.2013.10.021

92. Vonarbourg C, Mortha A, Bui VL, Hernandez PP, Kiss EA, Hoyler T, et al. Regulated expression of nuclear receptor ROR $\gamma \mathrm{t}$ confers distinct functional fates to NK cell receptor-expressing ROR $\gamma \mathrm{t}+$ innate lymphocytes. Immunity. (2010) 33:736-51. doi: 10.1016/j.immuni.2010.10.017

93. Cella M, Fuchs A, Vermi W, Facchetti F, Otero K, Lennerz JKM, et al. A human natural killer cell subset provides an innate source of IL-22 for mucosal immunity. Nature. (2008) 457:722. doi: 10.1038/nature07537

94. Cella M, Otero K, Colonna M. Expansion of human NK-22 cells with IL-7, IL-2, and IL-1 $\beta$ reveals intrinsic functional plasticity. Proc Natl Acad Sci USA. (2010) 107:10961-6. doi: 10.1073/pnas.1005641107

95. van Hoeven V, Munneke JM, Cornelissen AS, Omar SZ, Spruit MJ, Kleijer $\mathrm{M}$, et al. Mesenchymal stromal cells stimulate the proliferation and IL-22 production of group 3 innate lymphoid cells. J Immunol. (2018) 201:1165. doi: 10.4049/jimmunol.1700901

96. Ruiter B, Patil SU, Shreffler WG. Vitamins A and D have antagonistic effects on expression of effector cytokines and gut-homing integrin in human innate lymphoid cells. Clin Exp Allergy. (2015) 45:1214-25. doi: 10.1111/cea.12568

97. Cimbro R, Vassena L, Arthos J, Cicala C, Kehrl JH, Park C, et al. IL-7 induces expression and activation of integrin $\alpha 4 \beta 7$ promoting naive T-cell homing to the intestinal mucosa. Blood. (2012) 120:2610. doi: 10.1182/blood-2012-06-434779

98. Yang J, Cornelissen F, Papazian N, Reijmers RM, Llorian M, Cupedo $\mathrm{T}$, et al. IL-7-dependent maintenance of ILC3s is required for normal entry of lymphocytes into lymph nodes. J Exp Med. (2018) 215:1069. doi: $10.1084 /$ jem. 20170518

99. Spencer SP, Wilhelm C, Yang Q, Hall JA, Bouladoux N, Boyd A, et al. Adaptation of innate lymphoid cells to a micronutrient deficiency promotes type 2 barrier immunity. Science. (2014) 343:432-7. doi: $10.1126 /$ science. 1247606

100. Kim BS, Siracusa MC, Saenz SA, Noti M, Monticelli LA, Sonnenberg GF, et al. TSLP elicits IL-33-independent innate lymphoid cell responses to promote skin inflammation. Sci Transl Med. (2013) 5:170ra16. doi: $10.1126 /$ scitranslmed.3005374

101. Zhong C, Cui K, Wilhelm C, Hu G, Mao K, Belkaid Y, et al. Group 3 innate lymphoid cells continuously require the transcription factor GATA-3 after commitment. Nat Immunol. (2016) 17:169-78. doi: 10.1038/ni.3318.

102. Turner JE, Morrison PJ, Wilhelm C, Wilson M, Ahlfors H, Renauld JC, et al. IL-9-mediated survival of type 2 innate lymphoid cells promotes damage control in helminth-induced lung inflammation. J Exp Med. (2013) 210:2951-65. doi: 10.1084/jem.20130071

103. Sherrill JD, Gao P-S, Stucke EM, Blanchard C, Collins MH, Putnam PE, et al. Variants of thymic stromal lymphopoietin and its receptor associate with eosinophilic esophagitis. J Allergy Clin Immunol. (2010) 126:160-5.e3. doi: 10.1016/j.jaci.2010.04.037

104. Siracusa MC, Saenz SA, Hill DA, Kim BS, Headley MB, Doering TA, et al. TSLP promotes interleukin-3-independent basophil haematopoiesis and type 2 inflammation. Nature. (2011) 477:229-33. doi: 10.1038/nature10329 
105. Kabata H, Moro K, Fukunaga K, Suzuki Y, Miyata J, Masaki K, et al. Thymic stromal lymphopoietin induces corticosteroid resistance in natural helper cells during airway inflammation. Nat Commun. (2013) 4:2675. doi: $10.1038 /$ ncomms 3675

106. Kabata H, Moro K, Koyasu S, Fukunaga K, Asano K, Betsuyaku T. Mechanisms to suppress ILC2-induced airway inflammation. Ann Am Thorac Soc. (2016) 13(Suppl. 1):S95. doi: 10.1513/AnnalsATS.201508-557MG

107. Liu S, Verma M, Michalec L, Liu W, Sripada A, Rollins D, et al. Steroid resistance of airway type 2 innate lymphoid cells from patients with severe asthma: the role of thymic stromal lymphopoietin. J Allergy Clin Immunol. (2018) 141:257-68.e6. doi: 10.1016/j.jaci.2017.03.032

108. Kimura S, Pawankar R, Mori S, Nonaka M, Masuno S, Yagi T, et al. Increased expression and role of thymic stromal lymphopoietin in nasal polyposis. Allergy Asthma Immunol Res. (2011) 3:186-93. doi: 10.4168/aair.2011.3.3.186

109. Luo Y, Zhou B, Zhao M, Tang J, Lu Q. Promoter demethylation contributes to TSLP overexpression in skin lesions of patients with atopic dermatitis. Clin Exp Dermatol. (2014) 39:48-53. doi: 10.1111/ced.12206

110. Fornasa G, Tsilingiri K, Caprioli F, Botti F, Mapelli M, Meller S, et al. Dichotomy of short and long thymic stromal lymphopoietin isoforms in inflammatory disorders of the bowel and skin. J Allergy Clin Immunol. (2015) 136:413-22. doi: 10.1016/j.jaci.2015.04.011

111. Bjerkan L, Schreurs O, Engen SA, Jahnsen FL, Baekkevold ES, Blix IJ, et al. The short form of TSLP is constitutively translated in human keratinocytes and has characteristics of an antimicrobial peptide. Mucosal Immunol. (2015) 8:49-56. doi: 10.1038/mi.2014.41

112. Giacomin PR, Moy RH, Noti M, Osborne LC, Siracusa MC, Alenghat T, et al. Epithelial-intrinsic IKK $\alpha$ expression regulates group 3 innate lymphoid cell responses and antibacterial immunity. J Exp Med. (2015) 212:1513. doi: $10.1084 /$ jem.20141831

Conflict of Interest: The authors declare that the research was conducted in the absence of any commercial or financial relationships that could be construed as a potential conflict of interest.

Copyright $\odot 2019$ Sheikh and Abraham. This is an open-access article distributed under the terms of the Creative Commons Attribution License (CC BY). The use, distribution or reproduction in other forums is permitted, provided the original author(s) and the copyright owner(s) are credited and that the original publication in this journal is cited, in accordance with accepted academic practice. No use, distribution or reproduction is permitted which does not comply with these terms. 